\title{
Genetic parameters of somatic cell score and lactose content in goat's milk
}

\author{
E. Bagnicka ${ }^{1,3}$, M. Kukaszewicz $^{1}$ and T. Ådnøy ${ }^{2}$ \\ ${ }^{1}$ Institute of Genetics and Animal Breeding, Polish Academy of Sciences, \\ Department of Animal Improvement, Jastrzębiec, 05-552 Magdalenka, Poland \\ ${ }^{2}$ Norwegian University of Life Sciences, Department of Animal and Aquacultural Sciences, 1432 Ås, Norway
}

KEY WORDS: dairy goat, heritability, somatic cell score, lactose, genetic correlation, Legendre polynomials
Received: 4 September 2014

Revised: $\quad 22$ March 2016

Accepted: $\quad 19$ July 2016
${ }^{3}$ Corresponding author: e-mail: e.bagnicka@ighz.pl

\begin{abstract}
The aim of the study was to estimate the heritability and repeatability of somatic cell score (SCS) and lactose content, and also the genetic correlation between those and other dairy production traits. Milk yield, fat, protein and lactose content, and somatic cell count were recorded once a month for 11 years in a single herd, resulting in 4417 records from 282 does. The number of animals in pedigree was 11 659. An animal multiple-trait model accounted for breed, day of milking (Legendre polynomial regression on standardized days-in-milk), year of birth, year of milking, kidding season, litter size and parity. Variance components were estimated with the REML method using the DMU software. The highest content of lactose was found in the milk of primiparous goats which gave birth to one kid. The youngest goats had the lowest SCS. The heritabilities for SCS and lactose content were 0.21 and 0.27 , while repeatabilities were 0.31 and 0.55 , respectively. The genetic correlation between milk yield and lactose content was -0.46 , while between milk yield and SCS was 0.59 . The genetic correlations between lactose content and fat and protein contents were 0.62 and 0.54 , respectively. No correlations between SCS and protein, fat and lactose contents were found. Lactose content and SCS in goat's milk proved to be highly heritable which facilitates efficient inclusion of these traits in the breeding objective.
\end{abstract}

\section{Introduction}

The physiologically higher number of somatic cells in the goat's milk than in the cow's milk is mainly due to a high number of exfoliated cells. The results of our earlier study (Bagnicka et al., 2011) showed, that after removing the cytoplasmic particles together with fat, the exfoliated epithelial cells reached up to $67 \%$ of total somatic cell count (SCC) in healthy mammary gland. It is strongly evidenced that not only leukocytes but also epithelial cells play a crucial role in the initiation of inflammatory process (Rainard and Riollet, 2003); thus, the high SCC in goat's milk, including exfoliated epithelial cells, might be the reason for the low frequency of clinical mastitis in dairy goats.

Nonetheless, subclinical mastitis is also one of the main problems in dairy goat herds. The SCC in goat's milk should not be the sole indicator of bacterial infection of the goat mammary gland. About $20 \%$ of samples with somatic cells below $1 \times 106 \cdot \mathrm{ml}^{-1}$ contain bacterial pathogens, including those belonging to the major group. Moreover, many factors can affect the SCC level (Bagnicka et al., 2011). 
Therefore, the prediction of mammary gland inflammation based on SCC in goat is more difficult than in cattle or sheep (Rupp et al., 2011). Many different indicators of the mammary gland subclinical infection have been proposed, but the SCC is still the easiest and most cost-effective means of recording mammary gland health status also in goat breeding (Rupp et al., 2011). In addition, lactose content can also be used as the indicator of the mammary gland health status (Lindmark-Månsson et al., 2006).

The heritability coefficient of SCS has been estimated in dairy cattle populations for a long time and ranged from 0.00 to 0.29 (Kennedy et al., 1982; Coffey et al., 1985). In dairy sheep populations the somatic cell score (SCS - natural logarithm transformed SCC value) heritabilities ranged between 0.09 to 0.16 , while the genetic correlation between SCS and milk yield acquired values from moderate negative to moderate positive, depending on the sampled population (el-Saied et al., 1998; Barillet et al., 2001; Hamann et al., 2004). Nevertheless, the results of Rupp et al. (2009) and of McDougall et al. (2011) showed that it is possible to decrease the rate, duration and severity of mastitis in dairy sheep through SCC-based selection. Therefore, the economic indices for dairy goats, like in dairy cattle breeding, should also be broadened in the future, though the SCC heritability coefficient is low (Montaldo and Pelcastre-Cruz, 2012). To estimate genetic parameters of dairy traits in goat population, the breeders have been following methods employed in the dairy cattle and sheep breeding. First studies were based on lactation yields, while for the last two decades, the test-day model has been adapted in goat breeding, too. Usually the restricted maximum likelihood (REML) method or the Gibbs sampling with multiple-trait animal models are used to estimate the variance components (Groenewald and Viljoen, 2003; Rupp et al., 2011).

The Polish White Improved (PWI) and Polish Fawn Improved (PFI) are the main dairy goat breeds maintained in Poland. Our previous studies on the Polish dairy goat population indicated the lack of differences in production traits between these two breeds (Bagnicka et al., 2002, 2004, 2015). Detailed description of the Polish goat breeds was also presented by Kaba and Bagnicka (2009).

Few researches have been carried out on the genetic parameters of lactose content and SCC, so limited information is present in the literature about goat populations, while reliable variance components of novel traits are indispensable for including them in the best linear unbiased prediction (BLUP) genetic evaluations. Therefore, the aim of the study was to estimate the heritability and repeatability of SCC and lactose content, as well as the genetic correlation between those traits and other milk production traits.

\section{Material and methods}

The research has been conducted for 11 years in a single, milk recorded herd. Milk yield as well as fat, protein and lactose contents, and SCC were recorded once a month in all lactations resulting in 4417 records from 186 Polish White Improved (PWI) and 96 Polish Fawn Improved (PFI) does. The number of animals in the pedigree was 11659 . The recorded goats were descendants of 44 bucks and the pedigree was 5 generations deep. The bucks had: only one daughter (36\%), 2 - 5 daughters (32\%) and more than 5 daughters (32\%). There were only 65 goats out of 282 with no information about their parents. There were 112 test-day contemporary group classes while the year-of-milking effect had 11 classes. The data were further classified into 2 kidding seasons (October-March and April-September), 3 litter size classes with the $3^{\text {rd }}$ comprising more than 2 kids, and 5 classes of parity, with the $5^{\text {th }}$ containing lactations above the $4^{\text {th }}$ one (Table 1). Kids were weaned predominantly at the age of 3 weeks. The SCC distribution was normalized by the natural logarithm to SCS.

The differences between means were evaluated using the analysis of variance method with Tukey's multiple comparisons and Bonferroni's correction.

Table 1. Distribution of observations by breed, parity, season of kidding and litter size

\begin{tabular}{lc}
\hline Effect & No. of observations \\
\hline Breed & \\
PWI & \\
PFI $^{2}$ & 2815 \\
Parity & 1602 \\
1 & \\
2 & 1583 \\
3 & 1108 \\
$>3$ & 706 \\
Season of kidding & 1020 \\
October - March & \\
April - September & 3957 \\
Litter size & 460 \\
1 & \\
2 & 1295 \\
$>2$ & 2374 \\
\hline
\end{tabular}

${ }^{1} \mathrm{PWI}$ - Polish White Improved, ${ }^{2} \mathrm{PFI}$ - Polish Fawn Improved 
Subsequently, the REML computations were run with the DMU package of Madsen and Jensen (2000).

Milk yield, and fat, protein and lactose contents as well as SCS were analysed using a multiple-trait animal model presented in scalar notation as:

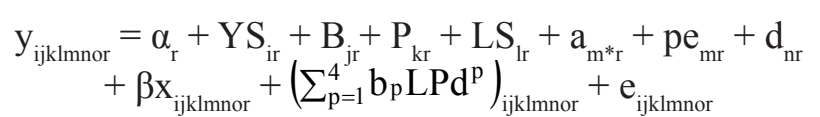

where: $\alpha_{\mathrm{r}}-$ intercept for trait $\mathrm{r} ; \mathrm{y}_{\mathrm{ijk} \text { lmnor }}-$ daily milk yield, and fat, protein and lactose content, and SCS $(\mathrm{r}=1, \ldots, 4) ; \mathrm{YS}_{\mathrm{ir}}$ - fixed effect of year-season of kidding $(\mathrm{I}=1, \ldots, 21)$ for trait $\mathrm{r} ; \mathrm{B}_{\mathrm{jr}}-$ fixed effect of breed $(j=1,2)$ for trait $r ; P_{k r}$ - fixed effect of parity $(\mathrm{k}=1, \ldots, 4)$ for trait $\mathrm{r} ; \mathrm{LS}_{\mathrm{lr}}$ - fixed effect of litter size $(1=1, \ldots, 3)$ for trait $\mathrm{r} ; \mathrm{a}_{\mathrm{m}^{*} \mathrm{r}}-$ random additive direct genetic effect of $\mathrm{m}$-th animal $\left(\mathrm{m}^{*}=1, \ldots, 11659\right)$ for trait $\mathrm{r}$; $\mathrm{pe}_{\mathrm{mr}}-$ random animal permanent environment effect $(m=1, \ldots, 282)$ for trait $r ; d_{n r}-$ random effect of milking date $(n=1, \ldots, 112)$ for trait $r$; $\beta \mathrm{x}_{\mathrm{ijklmnor}}-$ fixed regression of trait $\mathrm{r}$ on daily milk yield; $\left(\sum_{\mathrm{p}=1}^{4} \mathrm{~b}_{\mathrm{p}} \mathrm{LPd}^{\mathrm{p}}\right)_{\mathrm{ijk} \text { lmnor }}$ - fixed regression effect of trait $r$ on the Legendre $4^{\text {th }}$ degree polynomials of standardized days-in milk; $\mathrm{e}_{\mathrm{ijklmnor}}$-random residual for trait $r$.

Legendre polynomials of standardized days-in milk were computed as in Brotherstone et al. (2000).

\section{Results and discussion}

The average daily milk yield was $2.28 \pm 0.94 \mathrm{~kg}$ per doe with $3.60 \pm 0.93 \%, 2.97 \pm 0.44 \%$ and $4.57 \pm 0.33 \%$ of fat, protein and lactose content, respectively. The average SCS was $6.62 \pm 1.25$ which corresponded with the SCC of around 750000 .

Although no breed difference in lactose content was found, significantly higher content of lactose in milk was detected in the primiparous goats and in those having one kid than in goats of other parities or litter sizes (Table 2). The SCS differed only between the breeds and parities. The youngest goats had lowest SCS, which increased with the lactation number. Thus, the highest health status of the mammary gland was found in the primiparous goats. Barrón-Bravo et al. (2013) obtained similar results for breed and parity but not for litter size.

The heritabilities of SCS and lactose content were 0.21 of standard error (SE) equal to 0.06 and $0.27(\mathrm{SE}=0.05)$ while repeatabilities amounted to $0.31(\mathrm{SE}=0.03)$ and $0.55(\mathrm{SE}=0.03)$, respectively (Table 3). The correlation between milk yield and lactose content was high and negative $(-0.46)$, while between milk yield and SCS - high and positive
Table 2. Effect of breed, parity and litter size and standard errors (SE) for lactose content and somatic cell score (SCS)

\begin{tabular}{cllll}
\hline \multirow{2}{*}{ Effect } & \multicolumn{3}{c}{ Trait } \\
\cline { 2 - 5 } & lactose, $\%$ & SE & SCS & SE \\
\hline $\begin{array}{c}\text { Breed } \\
\text { PWI }\end{array}$ & 4.56 & 0.05 & $6.79^{\mathrm{A}}$ & 0.12 \\
$\mathrm{PFI}^{2}$ & 4.55 & 0.04 & $7.02^{\mathrm{B}}$ & 0.13 \\
Parity & & & & \\
1 & $4.62^{\mathrm{A}}$ & 0.05 & $6.47^{\mathrm{A}}$ & 0.19 \\
2 & $4.57^{\mathrm{B}}$ & 0.04 & $6.65^{\mathrm{Ba}}$ & 0.16 \\
3 & $4.57^{\mathrm{B}}$ & 0.04 & $6.77^{\mathrm{Bb}}$ & 0.13 \\
$>3$ & $4.52^{\mathrm{B}}$ & 0.02 & $6.91^{\mathrm{B}}$ & 0.09 \\
Litter size & & & & \\
1 & $4.57^{\mathrm{A}}$ & 0.02 & 6.75 & 0.09 \\
2 & $4.53^{\mathrm{B}}$ & 0.02 & 6.73 & 0.08 \\
3 & $4.49^{\mathrm{C}}$ & 0.02 & 6.79 & 0.07 \\
\hline
\end{tabular}

1,2 - see Table 1; ${ }^{A B C}$, ab means with different superscripts are significantly different at $P<0.01$ and $P<0.05$, respectively

Table 3. Genetic parameters and their standard error for lactose content and somatic cell score (SCS)

\begin{tabular}{lcllllll}
\hline \multirow{3}{*}{ Traits } & \multirow{2}{*}{$\begin{array}{l}\text { Herit- } \\
\text { ability }\end{array}$} & \multirow{2}{*}{$\begin{array}{l}\text { Repeat- } \\
\text { ability }\end{array}$} & $\begin{array}{l}\text { milk } \\
\text { yield, } \mathrm{kg}\end{array}$ & $\begin{array}{l}\text { fat, } \\
\%\end{array}$ & $\begin{array}{l}\text { protein, } \\
\%\end{array}$ & $\begin{array}{l}\text { lactose, } \\
\%\end{array}$ \\
\hline Lactose, $\%$ & 0.27 & 0.55 & -0.46 & 0.62 & 0.54 & - \\
& $(0.05)$ & $(0.03)$ & $(0.19)$ & $(0.13)$ & $(0.13)$ & \\
SCS & 0.21 & 0.31 & 0.59 & -0.19 & 0.00 & -0.14 \\
& $(0.06)$ & $(0.03)$ & $(0.22)$ & $(0.19)$ & $(0.18)$ & $(0.21)$ \\
\hline
\end{tabular}

$(0.59)$. The correlations between lactose content and fat or protein contents were also high and positive. There were no genetic correlations between SCS and the contents of fat, protein and lactose.

Until now, limited information exists about the heritabilities of SCC and lactose content in goat populations. Genetic parameters for SCC estimated in the French Saanen, Alpine and New Zealand dairy goat populations (mostly Saanen) were slightly lower than those obtained in our study $(0.20-0.24$ - Morris et al., 2011; Rupp et al., 2011). However, repeatability estimated by Morris et al. (2011) was almost the same as obtained in our study ( 0.57 vs 0.55$)$. Another New Zealand study on mixed-breed dairy goats (Saanen, Nubian, Alpine and Toggenburg) revealed that heritability of SCS is lactation stage dependent, and increased from 0.12 to 0.25 from the beginning to the end of lactation, while repeatability ranged between 0.46 and 0.59 (Apodaca-Sarabia et al., 2009). The value obtained in our study, higher than in the French population (Rupp et al., 2011), might have been the result of involving different animal populations and using different models. Heritability for SCC was also estimated in Kenya by Bett et al. (2012), however their estimates were much lower 
(0.15) than those previously mentioned and could be explained by the specific system of husbandry (low input smallholder systems in Kenya vs intensive systems in France, New Zealand or Poland).

Heritabilities for SCS obtained in different goat populations were higher than those in dairy cattle (first parity -0.11 , third parity -0.15 ) and more dependent on the parity than on the population (Pritchard et al., 2011; Rzewuska et al., 2011). Moreover, the heritability estimated for all parities, including cows with more than 5 parities, was only slightly higher ( 0.18 for the Irish dairy cattle; Berry and McCarthy, 2012). The heritabilities estimated in the Polish dairy cow population were also much lower $(0.128$ and 0.096 for the first and all lactations; Sender et al., 1998; Sender and Krencik, 2000) than those obtained in our study. The same phenomena are observed in dairy sheep. The estimates for the weighted lactation mean of cell scores ranged from 0.16 (Hamann et al., 2004) through 0.15 (Barillet et al., 2001), 0.13 (Rupp et al., 2002) to 0.10 (Barillet et al., 2009) or even 0.04 (Baro et al., 1994). This probably means that the number of somatic cells is more heritable in the goat's milk than in milk from other animals like cow or sheep. Thus, the breeding work towards lowering the milk SCC in goat as an indirect indicator of subclinical mastitis should be more efficient than in dairy cattle or sheep.

Heritability for lactose content was estimated only in the Norway dairy goat population using different methods and software (Andonov et al., 2007) and in the Brazilian population of Alpine and Saanen goats (Brito et al., 2011). The estimations in a Norwegian population ranged between 0.29 and 0.35 , and were slightly higher than those obtained in the presented study. Similar heritability (0.35) was presented by Morris et al. (2011) but for lactose yield. However, the lactose content found by Brito et al. (2011) was much lower (0.17) than that presented in our and Andonov et al. (2007) studies. In the literature different results for lactose content in cow's milk are presented - from 0.17 to 0.36 , depending of the stage of lactation and parity with the lowest at the beginning of the first lactation (Ptak et al., 2012) up to an average heritability of 0.48 in the first, and 0.51 in the second and later parities (Miglior et al., 2007).

The genetic correlations between SCS and fat, protein or lactose contents, or yields were also estimated in the French and New Zealand dairy goat populations, while that between SCS and milk yield - in the French and Kenya populations (Morris et al., 2011; Rupp et al., 2011; Bett et al., 2012). There was no correlation or low positive correlation estimated for French goats (Rupp et al., 2011) depending on the breed of goats ( 0.00 for Alpine and 0.12 for Saanen goats), and low positive for the Kenya population (0.15). The differences between the French and our results might be explained by different structure of data and number of observations (huge number of records but only first lactation included in the French data vs all but much smaller number of lactations in our database) and by the fact, that only one herd is included in our study that decreases the environmental variance component. However, genetic correlations between SCC and fat and protein contents were similar in both studies - there was no correlation (protein content) or correlation was low and negative (fat content). The results obtained in the Kenya population for SCC and daily milk yield were positive but low. While the correlation between SCS and lactose content in goat's milk has not been presented in the literature, the correlation between SCC and lactose yield was described by Morris et al. (2011) at a medium and negative level (-0.29). An unfavourable genetic correlation between SCS and milk yield $(0.13-0.15)$ was also reported for dairy goat, cattle and sheep populations (Barillet et al., 2001; Kadarmideen, 2004; Bett et al., 2012). An opposite result for sheep was noted for the genetic correlation between $\operatorname{logSCC}$ and milk yield: -0.23 (el-Saied et al., 1998), or even -0.37 (Baro et al., 1994). Genetic correlations between SCS and yield of fat or protein in cow's milk were 0.10 and 0.15 (Kadarmideen, 2004) or 0.125 and 0.132 (Sender and Krencik, 2000), respectively, and depended on examinated population. Genetic correlations between SCS and fat, protein or lactose contents obtained by Lindmark-Månsson et al. (2006) for dairy cattle were different from those obtained in our study $(-0.050,0.393$ and -0.774 , respectively), but correlation between $\operatorname{logSCC}$ and protein content in dairy sheep was closer to our result ( 0.37 vs 0.54 ; Baro et al., 1994). The genetic correlation between milk yield and lactose content estimated by Brito et al. (2011) in the Brazilian population is different from our result $(0.15 \mathrm{vs}-0.46)$.

Our results did not differ substantially from those obtained in other populations of goats, as well as of cows and sheep. They were obtained from only one herd, so the environmental conditions were exactly the same across the classes of year-season of kidding and year-season of milking. PWI and PFI goats were maintained in the same herd and there were no differences in productivity between these two breeds. Like other large goat herds in Poland, our herd was located in the central part of the country and was kept under intensive maintenance 
conditions. Also, these two breeds used in the study are the most popular in our country and a significant number of breeding bucks have originated from this herd. Thus, it can be assumed that results obtained in this herd are representative for the majority of large dairy goat herds in Poland.

\section{Conclusions}

Both lactose content and somatic cell number in goat's milk seem to be highly heritable. So including these traits in economic indices should result in ameliorating the resistance of animals to clinical and subclinical mastitis.

\section{References}

Andonov S., Ødegård J., Boman I.A., Svendsen M., Holme I.J., Ådnøy T., Vukovic V., Klemetsdal G., 2007. Validation of testday models for genetic evaluation of dairy goats in Norway. J. Dairy Sci. 90, 4863-4871

Apodaca-Sarabia C.A., Lopez-Villalobos N., Blair H.T., Prosser C.G., 2009. Genetic parameters for somatic cell score in dairy goats estimated by random regression. Proc. New Zeal. Soc. An. 69, 206-209

Bagnicka E., Distl O., Hamann H., Łukaszewicz M., 2004. Heritabilities of and genetic correlations between the dairy traits in goats estimated in first vs later lactations. Anim. Sci. Pap. Rep. 22, 205-213

Bagnicka E., Hamann H., Distl O., 2015. Structure and the non-genetic and genetic effects on milk traits in Polish dairy goat population. Anim. Sci. Pap. Rep. 33, 59-69

Bagnicka E., Łukaszewicz M., Distl O., Hamann H., 2002. Genetic and environmental trends in the Polish dairy goat population. Anim. Sci. Pap. Rep. 20, 195-202

Bagnicka E., Winnicka A., Jóźwik A., Rzewuska M., Strzałkowska N., Kościuczuk E., Prusak B., Kaba J., Horbańczuk J., Krzyżewski J., 2011. Relationship between somatic cell count and bacterial pathogens in goat's milk. Small Ruminant Res. $100,72-77$

Barillet F., Astruc J.M., Lagriffoul G., Aguerre X., Bonaïti B., 2009. Selecting milk composition and mastitis resistance by using a part lactation sampling design in French Manech red faced dairy sheep breed. ICAR Tech. Ser. 13, 129-135

Barillet F., Rupp R., Mignon-Grasteau S., Astruc J.-M., Jacquin M., 2001. Genetic analysis for mastitis resistance and milk somatic cell score in French Lacaune dairy sheep. Genet. Sel. Evol. 33, 397-415

Baro J.A., Carriedo J.A., San Primitivo F., 1994. Genetic parameters of test day measures for somatic cell count, milk yield, and protein percentage of milking ewes. J. Dairy Sci. 77, 2658-2662

Barrón-Bravo O.G., Gutiérrez-Chávez A.J., Ángel-Sahagún C.A., Montaldo H.H., Shepard L., Valencia-Posadas M., 2013. Losses in milk yield, fat and protein contents according to different levels of somatic cell count in dairy goats. Small Ruminant Res. 113, 421-431

Berry D.P., McCarthy J., 2012. Genetic and non-genetic factors associated with milking order in lactating dairy cows. Appl. Anim. Behav. Sci. 136, 15-19
Bett R.C., Gicheha M.G., Kosgey I.S., Kahi A.K., Peters K.J., 2012. Economic values for disease resistance traits in dairy goat production systems in Kenya. Small Ruminant Res. 102,135-141

Brito L.F., Silva F.G., Melo A.L.P., Caetano G.C., Torres R.A., Rodrigues M.T., Menezes G.R.O., 2011. Genetic and environmental factors that influence production and quality of milk of Alpine and Saanen goats. Genet. Mol. Res. 10, 3794-3802

Brotherstone S., White I.M.S., Meyer K., 2000. Genetic modelling of daily milk yield using orthogonal polynomials and parametric curves. Anim. Sci. 70, 407-415

Coffey E.M., Vinson W.E., Pearson R.E., 1985. Heritabilities for lactation average of somatic cell counts in first, second, and third or later parities. J. Dairy Sci. 68, 3360-3362

el-Saied U.M., Carriedo J.A., San Primitivo F., 1998. Heritability of test day somatic cell counts and its relationship with milk yield and protein percentage in dairy ewes. J. Dairy Sci. 81, 2956-2961

Groenewald P.C.N., Viljoen C.S., 2003. A Bayesian model for the analysis of lactation curves of dairy goats. J. Agric. Biol. Envir. S. 8, 75-83

Hamann H., Horstick A., Wessels A., Distl O., 2004. Estimation of genetic parameters for test day milk production, somatic cell score and litter size at birth in East Friesian ewes. Livest. Prod. Sci. 87, 153-160

Kaba J., Bagnicka E., 2009. Breeding of dairy goats in Poland. Dairy Goat J. 87, 46-49

Kadarmideen H.N., 2004. Genetic correlations among body condition score, somatic cell score, milk production, fertility and conformation traits in dairy cows. Anim. Sci. 79, 191-201

Kennedy B.W., Sethar M.S., Moxley J.E., Downey B.R., 1982. Heritability of somatic cell count and its relationship with milk yield and composition in Holsteins. J. Dairy Sci. 65, 843-847

Lindmark-Månsson H., Bränning C., Aldén G., Paulsson M., 2006. Relationship between somatic cell count, individual leukocyte population and milk components in bovine udder quarter milk. Int. Dairy J. 16, 717-727

Madsen P., Jensen J., 2000. A User's Guide to DMU. A Package for Analysing Multivariate Mixed Models. Version 6, Release 4. Unviversity of Aarhus, Research Centre Foulum. Tjele (Denmark)

McDougall S., Lopez-Villalobos N., Prosser C.G., 2011. Relationship between estimated breeding value for somatic cell count and prevalence of intramammary infection in dairy goats. New Zeal. Vet. J. 59, 300-304

Miglior F., Sewalem A., Jamrozik J., Bohmanova J., Lefebvre D.M., Moore R.K., 2007. Genetic analysis of milk urea nitrogen and lactose and their relationships with other production traits in Canadian Holstein cattle. J. Dairy Sci. 90, 2468-2479

Montaldo H.H., Pelcastre-Cruz A., 2012. Factors affecting genetic correlation estimates from dairy sires' genetic evaluations to assess genotype-environment interaction. Anim. Sci. Pap. Rep. 30, 309-315

Morris C.A., Wheeler M., Foote B.J., 2011. Relationships between live weight and herd-test traits in a Saanen goat herd in New Zealand. New Zeal. J. Agr. Res. 54, 315-320

Pritchard T.C., Mrode R., Coffey M.P., Wall E., 2011. Combination of test day somatic cell count and incidence of mastitis for the genetic evaluation of udder health. Interbull Bull. 44, 26-29

Ptak E., Brzozowski P., Bieniek J., 2012. Genetic parameters for lactose percentage in the milk of Polish Holstein-Friesians. J. Anim. Feed Sci. 21, 251-262 
Rainard P., Riollet C., 2003. Mobilization of neutrophils and defense of the bovine mammary gland. Reprod. Nutr. Dev. 43, 439-457

Rupp R., Bergonier B., Dion S., Hygonenq M.C., Aurel M.R., RobertGranié C., Foucras G., 2009. Response to somatic cell count-based selection for mastitis resistance in a diver-gent selection experiment in sheep. J. Dairy Sci. 92, 1203-1219

Rupp R., Boichard D., Barbat A., Astruc J.M., Lagriffoul G., Barillet F., 2002. Selection for mastitis resistance in French dairy sheep. In: Proceedings of the $7^{\text {th }}$ World Congress on Genetics Applied to Livestock Production. Montpellier (France). Communication No. $09-28$

Rupp R., Clément V., Piacere A., Robert-Granié C., Manfredi E., 2011. Genetic parameters from milk somatic cell score and relationship with production and udder type traits in dairy Alpine and Saanen primiparous goats. J. Dairy Sci. 94, 3629-3634
Rzewuska K., Jamrozik J., Żarnecki A., Strabel T., 2011. Genetic parameters of test-day somatic cell scores for the first three lactations of Polish Holstein-Friesian cattle. Czech J. Anim. Sci. 56, 381-389

Sender G., Krencik D., 2000. Somatic cell count - recording and evaluation. Interbull Bull. 25, 151-153

Sender G., Łukaszewicz M., Dorynek Z., Rosochowicz L., 1998. Genetic evaluation of somatic cell count in Friesian cows from NorthWest Poland. Anim. Sci. Pap. Rep. 16, 19-23 